\title{
Producción y calidad de forraje en mezclas de veza común con cebada, avena y triticale en cuatro etapas fenológicas
}

\author{
Forage production and quality of common vetch mixtures \\ with barley, oat and triticale in four phenological stages
}

\author{
Manuel de Jesús Flores Nájeraa, Ricardo A. Sánchez Gutiérreza, Francisco G. Echavarría \\ Cháireza, Ramón Gutiérrez Lunaa, Cesar A. Rosales Nietob, Homero Salinas Gonzálezc
}

\begin{abstract}
RESUMEN
Para determinar la producción y la calidad del forraje de la mezcla de veza común con cebada, avena, y triticale en dos proporciones de semilla $(65: 35 ; 35: 65)$ durante cuatro etapas fenológicas, se estableció un experimento en un diseño de bloques completos al azar con arreglo factorial $(3 \times 4 \times 4)$ con cuatro repeticiones. En mezclas de cultivos la mayor producción de materia seca (MS) la obtuvo la asociación avena-veza con $16.6 \mathrm{t}$ ha-1 y en proporción de cultivos la avena-veza $(65: 35)$ produjo $19.9 \mathrm{t} \mathrm{ha}^{-1}$, durante la etapa grano masoso $(P<0.001)$. La mayor cantidad de proteína cruda la obtuvieron las mezclas avena-veza (178 $\left.\mathrm{g} \mathrm{kg}^{-1} \mathrm{MS}\right)$ y triticale-veza $\left(161 \mathrm{~g} \mathrm{~kg}^{-1} \mathrm{MS}\right)$ durante la etapa de embuche. Los menores valores de fibra detergente neutra los presentaron el monocultivo veza y su mezcla con avena (35:65), durante la etapa grano maduro $(P<0.001)$. Las menores cantidades de fibra detergente ácida lo obtuvieron los monocultivos avena, veza y triticale durante la etapa grano lechoso $(P<0.001)$. El mayor porcentaje de nutrientes digestibles totales lo obtuvo el monocultivo veza y su mezcla con cebada (65:35) durante la etapa grano lechoso, respectivamente $(\boldsymbol{P}<\mathbf{0 . 0 0 1})$. El contenido de energía neta de lactación y el valor relativo de forraje fue mayor para el monocultivo veza $(\boldsymbol{P}<0.001)$. Se concluye que la producción y calidad del forraje en mezcla de veza con cereales (cebada, avena y triticale) dependen de la etapa de cosecha. En este estudio, la mezcla avena-veza logró mayor producción de materia seca y mejor contenido de proteína cruda. Además, el valor relativo del forraje fue más alto durante la etapa grano maduro.
\end{abstract}

PALABRAS CLAVE: Monocultivos, Cultivos asociados, Epoca de cosecha, Calidad del forraje.

\begin{abstract}
The objective was to determine forage yield and quality of vetch mixtures with barley, oat and triticale in two seeding

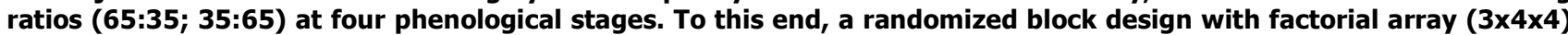
and four replications was established. The greatest dry matter yield was obtained from the oat-vetch mixture at the grain doughy stage of maturity $(16.6 \mathrm{t} \mathrm{ha}-1, P<0.00)$, while the seed proportion with the highest production was from the oat-vetch (65:35) ratio with $19.9 \mathrm{t} \mathrm{ha}^{-1}$ during the dough grain stage. The highest amount of crude protein was obtained from the oat-vetch (178 g kg-1 MS) and triticale-vetch (161 $\left.\mathrm{g} \mathrm{kg}^{-1} \mathrm{MS}\right)$ mixtures during booting stage. The monoculture vetch and oats-vetch (35:65) proportion, both had lower amounts of neutral detergent fiber at the mature grain stage $(P<0.001)$. The oat, vetch and triticale monocultures showed the lowest acid detergent fiber during milky grain stage $(P<0.001)$. The greatest percentage of TDN was observed in vetch monoculture and its mixtures with barley $(65: 35)$ during the milky grain stage, respectively $(P<0.001)$. The monoculture vetch provided highest values for NEL and RFV $(P<0.001)$. In conclusion, the forage yield and quality of vetch mixtures with barley, oat and triticale depend on the maturity stage. Also, the oat-vetch mixture showed the greatest dry matter yield and high CP concentration. In addition, forage relative value was higher during the mature grain stage.
\end{abstract}

KEY WORDS: Monocultures, Intercropping, Harvesting stage, Forage quality.

Recibido el 15 de mayo de 2015. Aceptado el 13 de agosto de 2015.

a Campo Experimental Zacatecas. INIFAP. Km. 24.5 Carretera Zacatecas-Fresnillo, 98500 Calera de Víctor Rosales, Zacatecas, México.

b Campo Experimental San Luis. INIFAP. San Luis Potosí. México.

c Centro de Investigación Regional Norte Centro. INIFAP. Blvd. José Santos Valdez 1200 Poniente. 27440 Matamoros, Coahuila. México. salinas.homero@hotmail.com. Correspondencia al último autor. 


\section{INTRODUCCIÓN}

La mezcla de cultivos o también llamado intercultivos es definida como el crecimiento simultaneo de dos o más especies durante una misma estación de crecimiento(1). Históricamente, el tipo de inter-cultivos anuales conocidos ampliamente en el mundo es la combinación de un cereal con una leguminosa, pues permite que la inclusión de la leguminosa mejore la producción y la calidad del forraje(2). En esta asociación, los cereales se caracterizan por aportar una alta producción de materia seca, pero con bajo contenido de proteína cruda, lo que disminuye su calidad y valor nutritivo(3). En cambio, las leguminosas presentan aceptable producción de forraje, pero han sido reconocidas ampliamente como una fuente rica en proteína cruda(4). Una de las leguminosas anuales ampliamente usadas como intercultivo con cereales es la veza común o ebo (Vicia sativa L), una leguminosa anual con un hábito de crecimiento trepador y con altos niveles de proteína cruda $(5,6)$. Respecto a cereales, se han propuesto un gran número de especies que figuran ser los apropiados para intercalarlos con la veza, entre los que destaca el maíz (Zea mays), la avena (Avena sativa L.), la cebada (Hordeum vulgare L.), el triticale ( $x$ Triticosecale Wittmack. Ex. A. Camus) y el trigo (Triticum aestivum L. emend. Thell)( $(7,8,9)$.

Estudios previos han demostrado que la cebada produce mayor cantidad de forraje que la avena, triticale o trigo, cuando es mezclada con la veza $(8,10)$. En cambio, Caballero y Goicoechea( 7$)$ y Thomson et $a(8)$ encontraron que el cereal más adecuado para mezclar con la veza es la avena. Sin embargo, Anil et a ${ }^{(5)}$ reportaron que el triticale puede ser usado como un cereal alternativo para mezclarlo con la veza.

Otro factor que puede modificar la producción y la calidad del forraje de la mezcla es la proporción de semilla utilizada por cultivo. Algunos autores sugieren rangos que van desde los 20 hasta los $80 \mathrm{~kg} \mathrm{ha}^{-1}$ para los cereales, mientras que para la veza común fluctúan entre

\section{INTRODUCTION}

Mixed cropping or also called intercropping is defined as the simultaneous growth of two or more species during a single growing season(1). Historically, the type of annual intercrops widely recognized in the world is the combination of a cereal with a legume, by allowing the inclusion of legumes production and improving forage quality(2). In this partnership, cereals characteristically provide high dry matter yields, but low crude protein content; this lowers its quality and nutritional value(3). In comparison, legumes have acceptable forage yields; however, they are widely recognized as a rich source of crude protein(4). One of the annual legumes widely used for intercropping with cereals is the common vetch or vetch (Vicia sativa L.), an annual legume with a climbing growth habit and high levels of crude protein $(5,6)$. With respect to cereals, a large number of species have been listed to be appropriate for combining them with vetch, among them are maize (Zea mays), oat (Oat sativa L.), barley (Hordeum vulgare L.), triticale ( $x$ Triticosecale Wittmack. Ex. A. Camus) and wheat (Triticum aestivum $L$. emend. Thell) $(7,8,9)$.

Previous studies have shown that barley produces more fodder than oat, triticale or wheat, when mixed with vetch $(8,10)$. In contrast, Knight and Goicoechea(7) and Thomson et $a(8)$ found that the most suitable for mixing with vetch cereal is oat. However, Anil et a $\mathbf{N}^{(5)}$ reported that triticale could be used as an alternative cereal for mixing with vetch.

Another factor that may modify the production and forage quality of the mixture is the seed ratio used for crop. Some authors suggest ranges varying from 20 to $80 \mathrm{~kg} \mathrm{ha}^{-1}$ for cereals, while for common vetch values suggested fluctuate between 20 and $50 \mathrm{~kg} \mathrm{ha}-1(11)$. Also, the harvest stage is another factor that may affect the production and quality of the forage. The plant quality continuously changes as it matures; in this state, the content of the cell wall increases; this causes more lignin buildup 
los 20 y $50 \mathrm{~kg}$ ha-1(11). También, la etapa de cosecha es otro factor que puede afectar la producción y la calidad del forraje. La planta continuamente cambia de calidad conforme va madurando; en este estado, el contenido de la pared celular incrementa; esto representa que se acumule más lignina, compuesto indigestible que resulta posteriormente en una disminución de la calidad del forraje(4). Se sugiere la etapa vegetativa como la mejor etapa de cosecha debido a que se puede utilizar para cualquier tipo de ganado y en cualquier etapa productiva(12).

En este contexto, el objetivo del presente estudio fue medir la producción y la calidad del forraje de la mezcla de veza común con cebada, avena y triticale, en dos proporciones de semilla (65:35; 35:65), en cuatro etapas fenológicas de cosecha.

\section{MATERIAL Y MÉTODOS}

Sitio de estudio

El trabajo se desarrolló en el Campo Experimental Zacatecas perteneciente al Instituto Nacional de Investigaciones Forestales, Agrícolas y Pecuarias (INIFAP), ubicado a $22^{\circ} 54^{\prime}$ $\mathrm{N}$ y $102^{\circ} 39^{\prime} \mathrm{O}$ y $2,197 \mathrm{msnm}$, con temperatura media anual de $14.6{ }^{\circ} \mathrm{C}$ y precipitación media anual de $416 \mathrm{~mm}$, la cual se presenta en mayor proporción en verano (junio a septiembre). El suelo del área de estudio es clasificado como Kastañozem, con un pH de 7.5, $1.26 \%$ de materia orgánica y textura franco arenosa(13). El terreno donde se sembraron las asociaciones de cultivos fue homogéneo en fertilidad, textura y pendiente.

\section{Manejo del cultivo y diseño experimental}

La mezcla de cultivos se estableció en una superficie de 1.78 ha, dividida en 0.81 ha para la siembra de cebada-veza, 0.52 ha para avenaveza y 0.45 ha para triticale-veza. Las variedades empleadas fueron cebada capuchona (Hordeum vulgare L.), avena chihuahua (Avena sativa L.), resulting in indigestible compound that consequently decreases forage quality $(4)$. The vegetative stage has been suggested as the best harvest stage because it can be used for any livestock type and productive stage(12).

In this context, the objective of this study was to measure the production and quality of forage mixture of common vetch with barley, oat and triticale, at two seed ratios (65:35; 35:65), within four phenological harvest stages.

\section{MATERIAL AND METHODS}

Study site

The work was carried out in the Zacatecas Experimental Station belonging to the National Institute of Forestry, Agriculture and Livestock (INIFAP), located at $22^{\circ} 54^{\prime} \mathrm{N}$ and $102^{\circ} 39^{\prime} \mathrm{W}$ and $2,197 \mathrm{~m}$ asl, with an average temperature of $14.6^{\circ} \mathrm{C}$ and annual rainfall of $416 \mathrm{~mm}$, of which the majority occurs during the summer (June to September). The soil of the study area is classified as Kastanozem, pH 7.5, $1.26 \%$ organic matter and with sandy loam texture(13). The land where crops associations were planted was homogeneous in fertility, texture and slope.

\section{Crop management and experimental design}

A combination of crops was established in an area of $1.78 \mathrm{ha}$, divided into 0.81 ha for planting Barley-Vetch, 0.52 ha for Oat-Vetch and 0.45 ha for Triticale-Vetch. The varieties used were capuchona barley (Hordeum vulgare L.), chihuahua oat (Oat sativa L.), Nazas river triticale (x Triticosecale Wittmack. Ex. A. Camus) and common vetch (Vicia sativa L.).

Site preparation consisted of a fallow period, tracking and leveling. Sowing was done on wet soil by November 14, 2013 for barley-vetch mixture, and November 22 for oat-vetch and triticale-vetch mixtures. For this a precision seeder was used, with a seeding density of 50 $\mathrm{kg}$ cereal seed with $20 \mathrm{~kg}$ of vetch. The dose of 80-46-00 fertilizer was applied; the sources 
triticale río nazas ( $x$ Triticosecale Wittmack. Ex. A. Camus) y veza común (Vicia sativa $L$.).

La preparación del terreno consistió de barbecho, rastreo y nivelación. La siembra se realizó en húmedo el 14 de noviembre de 2013 para la mezcla cebada-veza, y el 22 de noviembre para las mezclas avena-veza y triticale-veza. Para ello se utilizó una sembradora de precisión, con una densidad de siembra de $50 \mathrm{~kg}$ de semilla de cereal con $20 \mathrm{~kg}$ de veza. La dosis de fertilización fue de 80-46-00 usando como fuentes sulfato de amonio y superfosfato triple, aplicando todo el fósforo y la mitad del nitrógeno a la siembra, y el resto del nitrógeno en el primer riego de auxilio. El riego se proporcionó por gravedad, con sifones, aplicando cuatro riegos a un intervalo de 20 días, incluyendo el de siembra, con una lámina total aproximada de $40 \mathrm{~cm}$, estimada mediante el gasto conocido y el tiempo de riego.

Los tratamientos se establecieron con un diseño completamente al azar con arreglo factorial (3X4X4), donde el primer factor correspondió a la mezcla de cereales con veza definido por tres niveles: cebada-veza, avena-veza y triticaleveza, el segundo factor correspondió a la mezcla de cereales (cebada, avena, triticale) con veza en dos proporciones de semilla definido por cuatro niveles: monocultivo cereal 100\% (cebada, avena, triticale), cereal-veza proporción 65:35, cereal-veza proporción 35:65, monocultivo veza $(100 \%)$ y el tercer factor correspondió al estado fenológico de la cosecha definido por cuatro niveles: embuche, grano lechoso, grano masoso, y grano maduro con cuatro repeticiones por tratamiento. Las parcelas experimentales fueron 20 surcos de $55 \mathrm{~m}$ de largo con un espaciamiento de $0.75 \mathrm{~cm}$ entre ellas para la mezcla cebada + veza $\left(825 \mathrm{~m}^{2}\right)$ y para las mezclas de avena+veza y triticale+veza se utilizaron 20 surcos de $60 \mathrm{~m}$ de largo (900 $\left.\mathrm{m}^{2}\right)$.

Muestreos de rendimiento de forraje seco

Para estimar la producción de forraje verde y seco, de cada parcela se utilizaron dos surcos of these where from ammonium sulfate and triple superphosphate, applying all the phosphorous and half the nitrogen at planting, and the rest of nitrogen in the first supplementary irrigation. Four irrigations were applied by furrows irrigation at an interval of $20 \mathrm{~d}$, including planting, providing approximately a total of $40 \mathrm{~cm}$, this was estimated by measuring flow rate and time of irrigation.

The treatments were established with a completely randomized design with factorial arrangement $(3 \times 4 \times 4)$. The first factor corresponded to three different cereal mixtures with vetch and were defined as follows: barleyvetch, oat-vetch and triticale-vetch. The second factor corresponded the mixture of cereals (barley, oat, triticale) with two vetch seed ratios defined at four levels: $100 \%$ monoculture cereal (barley, oat, triticale), cereal-vetch ratio of 65:35, cereal-vetch ratio of 35 : 65 , a $100 \%$ vetch monoculture and the third factor that corresponded to the growth stage of the crop that was defined by four phenological stages: booting stage, milky, doughy grain, and mature grain with four replicates per treatment. The experimental plots were 20 rows by $55 \mathrm{~m}$ in length with a spacing of $0.75 \mathrm{~cm}$ between them for barley + vetch mixture $\left(825 \mathrm{~m}^{2}\right)$ and for the mixtures of oat + vetch and triticale + vetch 20 rows that were $60 \mathrm{~m}$ long were used $\left(900 \mathrm{~m}^{2}\right)$.

\section{Samplings dry forage yield}

To estimate the production of green and dry fodder, two rows of each plot were used that were $3 \mathrm{~m}$ long and had a spacing of $0.75 \mathrm{~m}$; the total area was $4.5 \mathrm{~m}^{2}$. Four samples were taken in each experimental plot, and these were carried out in a longitudinal to the surface of the plot. Each sampling was performed by cutting the forage with a sickle at a height of approximately $2 \mathrm{~cm}$ from the soil surface. To estimate the dry matter yield at each harvest, a $500 \mathrm{~g}$ sample of fresh forage was taken and placed to dry in an oven at $60{ }^{\circ} \mathrm{C}$ for $72 \mathrm{~h}$, which was subsequently transformed to tons of 
con un espaciado de $0.75 \mathrm{~m}$ entre ellos por $3 \mathrm{~m}$ de largo; el área total fue de $4.5 \mathrm{~m}^{2}$. Cuatro muestreos se realizaron en cada parcela experimental, y estos fueron llevados a cabo en forma longitudinal a la superficie de la parcela. Cada muestreo se realizó cortando el forraje con una rozadera a una altura aproximada de $2 \mathrm{~cm}$ de la superficie del suelo. Del forraje fresco cosechado, se tomó una muestra de $500 \mathrm{~g}$ para secarse en estufa a $60^{\circ} \mathrm{C}$ por $72 \mathrm{~h}$ para estimar el rendimiento de materia seca, que se transformó posteriormente a toneladas de materia seca por hectárea. Los cortes de forraje en la etapa de embuche fueron a los 85, 103 y 101 días después de la siembra (dds) para la asociación cebada-veza, avenaveza y triticale-veza, respectivamente. En la etapa grano lechoso los cortes de las mezclas cebada-veza, avena-veza y triticale-veza fueron hechos a los 92, 130 y 129 dds, respectivamente. En la etapa grano masoso los cortes de las mezclas cebada-veza, avena-veza y triticale-veza fueron hechos a los 106, 140 y 139 dds, respectivamente. En la etapa grano maduro los cortes de las mezclas cebada-veza, avena-veza y triticale-veza fueron hechos a los 118,150 y 165 dds, respectivamente.

\section{Calidad nutricional}

Las muestras de forraje con las que se determinaron los porcentajes de materia seca se procesaron en un molino Willy con criba de un milímetro. A todas las muestras se les determinó el porcentaje de proteina cruda (PC) mediante el método de Dumas por combustión $A O A C(14)$, utilizando el equipo LECO. El contenido de fibra detergente neutro (FDN) y fibra detergente ácido (FDA) se determinaron con la técnica de detergentes(15) usando un analizador de fibra ANKOM. Las variables nutrientes digestibles totales (NDT), valor relativo del forraje (VRF) y energía neta para lactación (ENL) se calcularon utilizando las ecuaciones adaptadas por Horroks y Vallentine(16).

Los datos de todas las variables se analizaron usando el procedimiento de modelos mixtos dry matter per hectare. The cuts of forage in the booting stage were carried out at 85, 103 and $101 \mathrm{~d}$ after sowing (dap) for barley-vetch, oat-vetch and triticale-vetch, respectively association. For the milky grain stage cuts of barley-vetch, oat-vetch and triticale-vetch mixtures were made at 92, 130 and 129 dap, respectively. Doughy stage grain cuts of barleyvetch, oat-vetch and triticale-vetch mixtures were made at 106, 140 and 139 dap, respectively. In mature grain stage cuts of barley-vetch, oat-vetch and triticale-vetch mixtures were made at 118, 150 and 165 dap, respectively.

\section{Nutritional quality}

The forage samples used to calculate percentages of dry matter was processed with a Willy mill with a millimeter sieve. All samples were analyzed for percentage of crude protein (CP) using the Dumas combustion method AOAC(14) using the LECO equipment. The neutral detergent fiber (NDF) and acid detergent fiber (ADF) were determined with the technique of detergents using an ANKOM fiber analyzer. The variables of total digestible nutrients (TDN), relative feed value (RFV) and net energy for lactation $\left(\mathrm{NE}_{\mathrm{L}}\right)$ were calculated using the equations adapted by Horroks and Vallentine(16).

Data for all variables were analyzed using mixed models procedure set by the estimation method (RML) of SYSTAT 13, Chicago, IL(17). The model included fixed effects of crop mixtures at three levels: barley-vetch, oat-vetch and triticale-vetch, with repetition as random factor; seeding ratios at four levels: monoculture cereal (barley, oats, triticale) $100 \%$, cereal-vetch ratio of $65: 35$ and cereal-vetch ratio of 35:65 and $100 \%$ vetch as well as crop growth stage with four levels: boot stage, milky, doughy grain and mature grain and their interactions, and the random effects of repetition and residual. The comparison between treatments for all variables was made by Tukey test. Data is presented as an average. 
ajustado por el método de estimación (RML) de SYSTAT 13, Chicago, IL(17). El modelo incluyó efectos fijos de mezclas de cultivos con tres niveles: cebada-veza, avena-veza y triticale-veza, con la repetición como factor aleatorio, proporción de siembra con cuatro niveles: monocultivo cereal (cebada, avena, triticale) $100 \%$, cereal-veza proporción 65:35, cerealveza proporción $35: 65$ y veza $100 \%$ y estado fenológico de cosecha con cuatro niveles: embuche, grano lechoso, grano masoso y grano maduro y sus interacciones, y los efectos aleatorios de la repetición y residual. La comparación entre tratamientos de todas las variables fue hecha mediante la prueba de Tukey. Los datos son presentados en promedio.

\section{RESULTADOS}

\section{Rendimiento de materia seca}

El análisis de modelos mixtos mostró un efecto significativo de la mezcla de cereales (avena, cebada, triticale) con la veza sobre la producción de materia seca (MS; $P<0.001$ ). Además, el efecto sobre la producción de MS difirió dependiendo de la etapa de cosecha $(P<0.001)$. Así, la mayor producción de MS la obtuvo la mezcla avena-veza durante la etapa grano masoso, mientras que la menor producción la obtuvo la mezcla cebada-veza durante la etapa de embuche (Cuadro 1).

Con respecto a la producción de MS evaluada por monocultivo (avena, cebada, triticale) y la mezcla de estos cereales con la veza en dos proporciones de semilla $(65: 35,35: 65)$, los resultados mostraron diferencias (Cuadro 2; $P<0.001$ ). Además, el efecto de la proporción de semilla sobre la producción de MS difirió dependiendo de la etapa de cosecha $(P<0.001)$. El monocultivo avena (17.2 t ha-1) y su mezcla con la veza (65:35; $\left.19.9 \mathrm{t} \mathrm{ha}^{-1}\right)$ presentaron mayores cantidades de MS durante la etapa grano masoso, mientras que la menor producción la obtuvieron los monocultivos cebada $(2.4 \mathrm{t})$ y veza $(2.6 \mathrm{t})$.

\section{RESULTS}

Dry matter yield

The mixed model analysis showed a significant effect of the mixture of cereals (oat, barley, triticale) with vetch on the production of dry matter (DM; $P<0.001$ ). Furthermore, the effect on the production of DM differ depending on the stage of harvest $(P<0.001)$. Thus, the highest production of DM was obtained by oat-vetch mixture during the doughy grain stage, while the lowest production was found with barleyvetch mixture during the boot stage (Table 1 ).

The results showed differences in regard to the production of DM in monocultures (oat, barley, triticale) and the mixture of these cereals with vetch seed in two ratios $(65: 35,35: 65)$, (Table 2; $P<0.001)$. Furthermore, the effect of the ratio of seed on the DM production differed depending on the stage of harvest $(P<0.001)$. Monoculture oat (17.2 $\left.\mathrm{t} \mathrm{ha}^{-1}\right)$ and its mixture with vetch

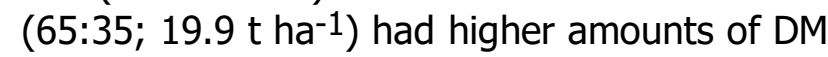
during the doughy grain stage, while the lower production was obtained with monocultures barley $(2.4 \mathrm{t})$ and vetch $(2.6 \mathrm{t})$.

\section{Nutritional quality}

Crude protein (CP) content among crop mixtures was different $(P<0.05$; Table 1$)$. In fact, the effect of the mixture of crops on the content of $\mathrm{CP}$ differ depending on the stage of harvest. The highest content of $\mathrm{CP}$ was obtained with oat-vetch mixtures and triticale-vetch during the boot stage, while the least was present in the barley-vetch and oat-vetch grain mixtures during the doughy stage.

The results with respect to $\mathrm{CP}$ content evaluated as a monoculture (oat, barley, triticale) and the mixture of these cereals with vetch seed in two ratios $(65: 35,35: 65)$ showed differences $(P<0.001$; Table 2$)$. Furthermore, the effect of the seed ratio with respect to $\mathrm{CP}$ content differed depending on the stage of harvest $(P<0.001)$. Thus, the highest CP was found with the vetch monoculture (294 $\mathrm{g} \mathrm{kg}^{-1}$ DM) during mature 
Cuadro 1. Diferencias en la producción de DM, CP, ADF, NDF, TDN, NEL and RFV entre asociaciones de cultivos en cuatro etapas fenológicas

Table 1. Differences in the production of DM, CP, ADF, NDF, TDN, NEL and RFV among crop associations in four phenological stages

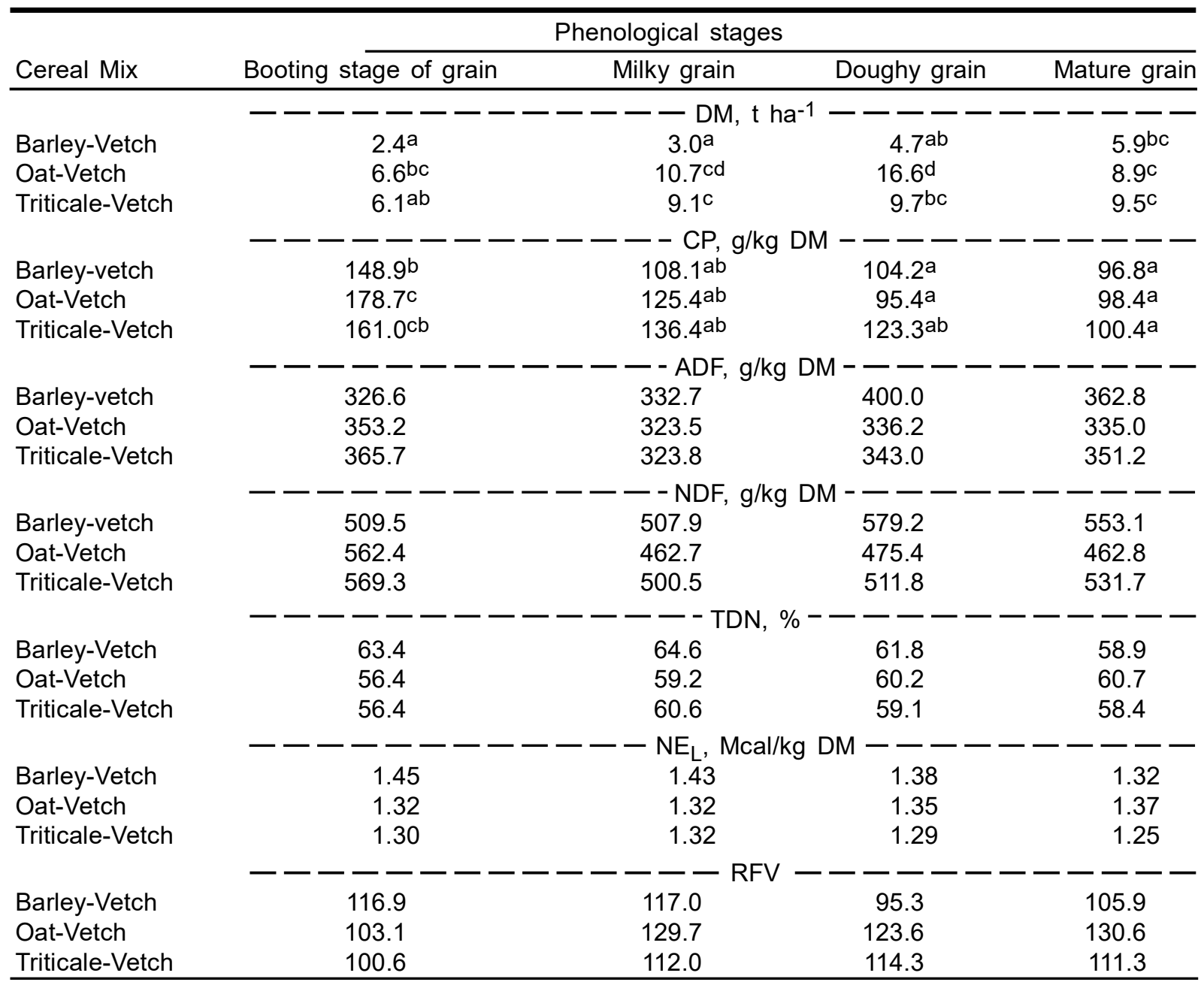

$\mathrm{DM}=$ Dry matter; $\mathrm{CP}=$ Crude protein; $\mathrm{ADF}=\mathrm{Acid}$ detergent fiber; NDF= Neutral detergent fiber; $T D N=$ Total digestible nutrients; $\mathrm{NE}_{\mathrm{L}}=$ Net energy for lactation; and $\mathrm{RFV}=$ Relative feed value.

abcd Different letters represent significant differences among treatments $(P<0.05)$.

\section{Calidad nutricional}

El contenido de PC entre mezclas de cultivos fue diferente ( $P<0.05$; Cuadro 1$)$. De hecho, el efecto de la mezcla de cultivos sobre el contenido de PC difirió dependiendo de la etapa de cosecha. El mayor contenido de PC lo obtuvieron las mezclas avena-veza y triticaleveza durante la etapa de embuche, mientras que la menor cantidad la presentaron las grain stage, followed by the seed ratio of oatvetch (35:65; $\left.175 \mathrm{~g} \mathrm{~kg}^{-1} \mathrm{DM}\right)$ during the boot stage. Minor amounts of CP were obtained by the barley and oat monocultures during the mature stages grain (56 g) and doughy grain $(60 \mathrm{~g})$, respectively.

NDF was not different between crop mixtures ( $P>0.05$; Table 1). There was also no effect 
mezclas cebada-veza y avena-veza durante la etapa grano masoso.

Con respecto al contenido de PC evaluada por monocultivo (avena, cebada, triticale) y la mezcla de estos cereales con la veza en dos between the mixture of crops and harvest stage on the NDF ( $P>0.05)$. However, there was a significant effect of seed ratio in the mixture on the NDF $(P<0.001)$. Furthermore, the effect of seed ratio on NDF content differed depending on the stage of harvest $(P<0.001$; Table 2$)$.

Cuadro 2. Diferencias en la producción de DM, CP y NDF de monocultivos (cebada, avena y triticale) y la mezcla de estos cereales con la veza en dos proporciones de semilla $(65: 35,35: 65)$

Table 2. Differences in the production of DM, CP and NDF in monocultures (barley, oat and triticale) and the mixture of these cereals with vetch in two seed ratios $(65: 35,35: 65)$

\begin{tabular}{|c|c|c|c|c|}
\hline \multirow[b]{2}{*}{ Cereal/ratio } & \multicolumn{4}{|c|}{ Phenological stages } \\
\hline & Booting stage of grain & Milky grain & Doughy grain & Mature grain \\
\hline & \multicolumn{4}{|c|}{$------------\mathrm{DM}\left(\mathrm{t} \mathrm{ha}^{-1}\right)----------$} \\
\hline Barley/100 & $2.4^{\mathrm{a}}$ & $3.2^{\mathrm{ab}}$ & $5.1 \mathrm{bc}$ & $6.2^{\mathrm{bcd}}$ \\
\hline Vetch/100 & $2.6^{\mathrm{a}}$ & $3.5^{\mathrm{ab}}$ & $4.2^{\mathrm{abc}}$ & $3.1 \mathrm{ab}$ \\
\hline Barley:veza/65:35 & $2.8^{a}$ & 3.3ab & 4.6abc & $5.9 \mathrm{bc}$ \\
\hline Barley:Vetch/35:65 & $2.8^{\mathrm{a}}$ & $3.3^{a b}$ & $5.0 \mathrm{bc}$ & $6.5^{\mathrm{bcd}}$ \\
\hline Oat/100 & $6.7 \mathrm{~cd}$ & $11.3^{f}$ & $17.2 \mathrm{gh}$ & $10.1^{f}$ \\
\hline Oat:Vetch/65:35 & $6.7^{\mathrm{cd}}$ & $11.7^{f}$ & $19.9^{h}$ & 9.3 def \\
\hline Oat:Vetch/35:65 & $7.3^{\text {cde }}$ & $11.0^{f}$ & 16.09 & 8.6 def \\
\hline Triticale/100 & $6.3^{b c d}$ & $9.4 \mathrm{def}$ & 9.1 def & 9.0 def \\
\hline Triticale:Vetch/65:35 & $6.7^{\mathrm{cd}}$ & $9.5^{\text {def }}$ & $10.1^{f}$ & $9.7 \mathrm{def}$ \\
\hline \multirow[t]{2}{*}{ Triticale:Vetch/35:65 } & $5.9 \mathrm{bc}$ & $9.2^{\mathrm{def}}$ & $10.7^{f}$ & $10.8^{f}$ \\
\hline & \multicolumn{4}{|c|}{ 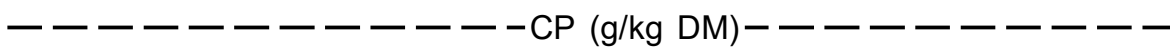 } \\
\hline Barley/100 & 104 bcde & $84^{a b}$ & $62^{a}$ & $56^{a}$ \\
\hline Vetch/100 & $288^{\mathrm{h}}$ & $243^{h}$ & $287^{\mathrm{h}}$ & $294^{\mathrm{h}}$ \\
\hline Barley:veza/65:35 & $118^{\mathrm{cde}}$ & $85^{a b}$ & $72^{a b}$ & $65^{a b}$ \\
\hline Barley:Vetch/35:65 & $155^{\mathrm{fg}}$ & $88^{a b}$ & $87 a b c$ & $71^{\mathrm{ab}}$ \\
\hline Oat/100 & 1649 & $82^{a b}$ & $60^{a}$ & $65^{a b}$ \\
\hline Oat:Vetch/65:35 & $142^{\text {efg }}$ & $94^{a b}$ & $61^{a}$ & $61^{a b}$ \\
\hline Oat:Vetch/35:65 & 1759 & $143^{\text {defg }}$ & $71^{a b}$ & $64^{a b}$ \\
\hline Triticale/100 & $145^{\mathrm{efg}}$ & $113^{\text {cde }}$ & 120 cdef & $75^{\mathrm{abc}}$ \\
\hline Triticale:Vetch/65:35 & $134^{\mathrm{efg}}$ & $123^{\text {def }}$ & $92^{\mathrm{abc}}$ & $62^{\mathrm{ab}}$ \\
\hline \multirow[t]{2}{*}{ Triticale:Vetch/35:65 } & 140 efg & 121 def & $76 \mathrm{ab}$ & $67 \mathrm{ab}$ \\
\hline & \multicolumn{4}{|c|}{ 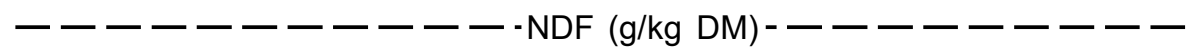 } \\
\hline Barley/100 & $510^{b c d e f}$ & 504 bcdef & $622^{i}$ & 586 fghi \\
\hline Vetch/100 & $429 a b$ & $400^{a}$ & $433^{a b c}$ & $363^{a}$ \\
\hline Barley:veza/65:35 & 524 cdefg & 530 cdefg & $588^{f g h i}$ & $586 \mathrm{fghi}$ \\
\hline Barley:Vetch/35:65 & $535^{\text {cdefgi }}$ & 544 defghi & 6019hi & $583^{\text {fghi }}$ \\
\hline Oat/100 & $586^{f g i}$ & $456 \mathrm{bc}$ & $492^{b c d e}$ & $478^{b c d}$ \\
\hline Oat:Vetch/65:35 & $5999 i$ & $484^{\text {bcde }}$ & $471^{b c d}$ & $491^{\text {cdef }}$ \\
\hline Oat:Vetch/35:65 & 569 efg & $479^{b c d e}$ & $484^{b c d e}$ & $407^{a}$ \\
\hline Triticale/100 & $605^{\mathrm{hi}}$ & $534^{\mathrm{fghi}}$ & $512^{\text {bcdef }}$ & $572^{\text {fghi }}$ \\
\hline Triticale:Vetch/65:35 & $612^{i}$ & 519defgh & $540^{\text {defghi }}$ & $553^{\text {defghi }}$ \\
\hline Triticale:Vetch/35:65 & 560 efghi & $499 \mathrm{bcde}$ & 524 fgh & $555^{\text {fghi }}$ \\
\hline
\end{tabular}

$\mathrm{DM}=$ Dry matter; $\mathrm{CP}=$ Crude protein; and NDF= Neutral detergent fiber.

abcdefghi Different letters represent significant differences among treatments $(P<0.05)$. 
proporciones de semilla $(65: 35,35: 65)$, los resultados mostraron diferencias $(P<0.001$; Cuadro 2). Además, el efecto de la proporción de semilla sobre el contenido de PC difirió dependiendo de la etapa de cosecha $(P<0.001)$. Así, la mayor cantidad de PC la presentó el monocultivo veza ( $294 \mathrm{~g} \mathrm{~kg}^{-1} \mathrm{MS}$ ) durante la etapa grano maduro, le siguió la proporción avena-veza (35:65; $175 \mathrm{~g} \mathrm{~kg}^{-1} \mathrm{MS}$ ) durante la etapa de embuche. Las menores cantidades de PC las obtuvieron los monocultivos cebada y avena durante las etapas grano maduro $(56 \mathrm{~g})$ y grano masoso $(60 \mathrm{~g})$.

La FDN no fue diferente entre mezclas de cultivos ( $P>0.05$; Cuadro 1). Tampoco hubo efecto entre la mezcla de cultivos y la etapa de cosecha sobre el contenido de FDN ( $P>0.05)$. Sin embargo, hubo un efecto significativo de la proporción de semilla en la mezcla sobre el contenido de FDN $(P<0.001)$. Además, el efecto de la proporción de semilla sobre el contenido de FDN difirió dependiendo de la etapa de cosecha ( $P<0.001$; Cuadro 2$)$. La menor cantidad de FDN la obtuvo el monocultivo veza (363 g kg-1 MS), le siguió la proporción avenaveza (35:65) con $407 \mathrm{~g} \mathrm{~kg}^{-1} \mathrm{MS}$, ambos datos obtenidos durante la etapa grano maduro, mientras que la mayor cantidad de FDN la presentó el monocultivo cebada $\left(622 \mathrm{~g} \mathrm{~kg}^{-1}\right.$ MS) durante la etapa grano masoso.

El contenido de FDA no fue diferente entre mezclas de cultivos ( $P>0.05$; Cuadro 1 ). No obstante, hubo un efecto de la proporción de semilla en las mezclas sobre el contenido de FDA $(P<0.01)$. Además, el efecto de la proporción de semilla sobre el contenido de FDA difirió dependiendo de la etapa de cosecha $(P<0.001$; Cuadro 3). Las menores cantidades de FDA las presentaron los monocultivos avena (305 g kg-1 MS), veza (306 g) y la proporción (35:65) triticale-veza (306 g) durante la etapa grano lechoso, mientras que las mayores cantidades la presentaron el monocultivo cebada $(416 \mathrm{~g})$, y la proporción cebada-veza 65:35 (409 g) durante la etapa grano masoso.
The least amount of NDF the vetch monoculture obtained (363 g kg-1 DM), followed oat-vetch ratio (35:65) with $407 \mathrm{~g} \mathrm{~kg}^{-1} \mathrm{DM}$, both data obtained during the mature grain stage, while NDF as much the present monoculture barley (622 $\mathrm{g} \mathrm{kg}^{-1} \mathrm{DM}$ ) during grain doughy stage.

The content of ADF did not differ between crop mixtures ( $P>0.05$; Table 1 ). However, there was an effect related to seed ratio in the mixtures with respect to ADF content $(P<0.01)$. Furthermore, the effect of the seed ratio on ADF content differed depending on the stage of harvest $(P<0.001$; Table 3$)$. Minor amounts of the ADF presented the oat monocultures (305 $\left.\mathrm{g} \mathrm{kg}^{-1} \mathrm{DM}\right)$, vetch $(306 \mathrm{~g})$ and ratio (35:65) triticale-vetch (306 g) during the milky stage, while larger amounts presented the monoculture barley $(416 \mathrm{~g})$, and barley-vetch 65:35 ratio (409 g) during the dough grain stage.

TDN content did not differ between crop mixtures ( $P>0.05$; Table 1$)$, but it was different in relation to the seed ratio in the mixture $(P<0.001)$. In fact, the effect of the seed ratio on the content of TDN differ depending on the stage of harvest $(P<0.01$; Table 3$)$. Thus, the highest amount of TDN was obtained by vetch monoculture with $66.7 \%$ during the milky stage. Followed, monoculture barley $(65.0 \%)$ and its mixture with vetch (35:65; $64 \%)$, both values obtained during the milky stage. The lowest percentage of TDN was obtained by vetch-triticale ratio (65:35), with $53.7 \%$ during the boot stage. Followed by oat monoculture $(54.4 \%)$ and its mixture with vetch $(65: 35 ; 54.6 \%)$, both during the boot stage. There was no interaction between the mix of crops and harvest stage on the content of TDN ( $P>0.05)$.

$\mathrm{NE}_{\mathrm{L}}$ values were not different between crop mixtures ( $P>0.05$; Table 1$)$. However, there was an effect of monocultures (barley, oat, triticale) and their mixture with vetch in two seed ratios (65:35; 35:65) on the content of $\mathrm{NE}_{\mathrm{L}}(P<0.001$; Table 3). The highest $\mathrm{NE}_{\mathrm{L}}$ was found with the vetch monoculture with 1.62 Mcal kg-1 DM. There was no effect with harvest stage on the 
El contenido de NDT no fue diferente entre mezclas de cultivos ( $P>0.05$; Cuadro 1 ), pero sí fue diferente en relación a la proporción de semilla en la mezcla $(P<0.001)$. De hecho, el efecto de la proporción de semilla sobre el contenido de NDT difirió dependiendo de la etapa de cosecha $(P<0.01 ;$ Cuadro 3). Así, la net energy of lactation ( $P>0.05)$, nor with the interaction between the seed ratio mixtures and harvest stage on $\mathrm{NE}_{\mathrm{L}}(P>0.05)$.

Relative feed value (RFV) did not differ between crop mixtures ( $P>0.05$; Table 1$)$. There was also no interaction between the cereal mixture

Cuadro 3. Diferencias en la producción de ADF, TDN y NE $\mathrm{L}$ de monocultivos (cebada, avena y triticale) y la mezcla de estos cereales con la veza en dos proporciones de semilla $(65: 35,35: 65)$

Table 3. Differences in the production of $A D F, T D N$ and $\mathrm{NE}_{\mathrm{L}}$ in monocultures (barley, oat and triticale) and the mixture of these cereals with two vetch seed ratios $(65: 35,35: 65)$

\begin{tabular}{|c|c|c|c|c|}
\hline \multirow[b]{2}{*}{ Cereal/ratio } & \multicolumn{3}{|c|}{ Phenological stages } & \multirow[b]{2}{*}{ Mature grain } \\
\hline & Booting stage of grain & Milky grain & Doughy grain & \\
\hline & \multicolumn{4}{|c|}{----------1 ADF $(\mathrm{g} / \mathrm{kg} \mathrm{DM})----------$} \\
\hline Barley/100 & $323^{a b}$ & $355^{a b c}$ & $416^{\mathrm{d}}$ & $380^{\mathrm{bcd}}$ \\
\hline Vetch/100 & $311^{a}$ & $306^{a}$ & $388^{\mathrm{cd}}$ & $307 a$ \\
\hline Barley:veza/65:35 & $322 \mathrm{ab}$ & $330 \mathrm{abc}$ & 409d & $373 \mathrm{bcd}$ \\
\hline Barley:Vetch/35:65 & $343 a b c$ & $327 a b c$ & $382^{b c}$ & $364 a b c$ \\
\hline Oat/100 & $356 \mathrm{abc}$ & $305^{a}$ & $334 \mathrm{abc}$ & $322^{a b c}$ \\
\hline Oat:Vetch/65:35 & $380^{\mathrm{bc}}$ & $341 \mathrm{abc}$ & $312^{\mathrm{abc}}$ & $324 \mathrm{abc}$ \\
\hline Oat:Vetch/35:65 & $345 \mathrm{abc}$ & $333 a b c$ & $331 \mathrm{abc}$ & $362^{a b c}$ \\
\hline Triticale/100 & $374 \mathrm{bcd}$ & $342^{a b c}$ & $323 a b$ & $395^{\mathrm{cd}}$ \\
\hline Triticale:Vetch/65:35 & $380^{b c d}$ & $333 a b c$ & $355^{\mathrm{abcd}}$ & $346 a b c$ \\
\hline \multirow[t]{2}{*}{ Triticale:Vetch/35:65 } & $371 \mathrm{bcd}$ & $306^{a}$ & $330 \mathrm{abc}$ & $335 \mathrm{abc}$ \\
\hline & \multicolumn{4}{|c|}{ 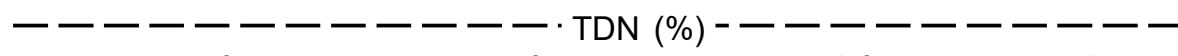 } \\
\hline Barley/100 & 63.9efg & $65.0^{\mathrm{fg}}$ & $61.8^{\mathrm{cdef}}$ & $58.0^{\mathrm{bc}}$ \\
\hline Vetch/100 & $65.9^{f g}$ & 66.79 & $61.9 \mathrm{cdef}$ & $63.7^{\text {efg }}$ \\
\hline Barley:veza/65:35 & 63.0cdef & 63.9 efg & 62.1 def & $61.9 \mathrm{bcd}$ \\
\hline Barley:Vetch/35:65 & $62.1^{\text {cdef }}$ & $64.0^{\mathrm{efg}}$ & $61.2^{\text {bcdef }}$ & $57.7 \mathrm{ab}$ \\
\hline Oat/100 & $54.4^{a}$ & $59.0^{\mathrm{bcd}}$ & $59.5^{b c d e}$ & $60.3^{b c d e}$ \\
\hline Oat:Vetch/65:35 & $54.6^{a}$ & $56.5^{\mathrm{ab}}$ & $61.0^{\text {bcde }}$ & $59.7 \mathrm{bcde}$ \\
\hline Oat:Vetch/35:65 & $55.3 a b$ & $58.3^{a b c d}$ & $59.3 \mathrm{bcde}$ & $60.5^{\mathrm{bcde}}$ \\
\hline Triticale/100 & $55.7^{a}$ & $60.8^{\mathrm{bcde}}$ & $58.5^{\mathrm{bcde}}$ & $57.8^{\mathrm{b}}$ \\
\hline Triticale:Vetch/65:35 & $53.7^{a}$ & $58.8^{\mathrm{bcde}}$ & $57.8^{b}$ & $57.8^{\mathrm{b}}$ \\
\hline \multirow[t]{2}{*}{ Triticale:Vetch/35:65 } & $55.7^{a}$ & $60.8^{b c d e f}$ & $58.5^{\mathrm{bcd}}$ & $57.8^{\mathrm{bcd}}$ \\
\hline & \multicolumn{4}{|c|}{ 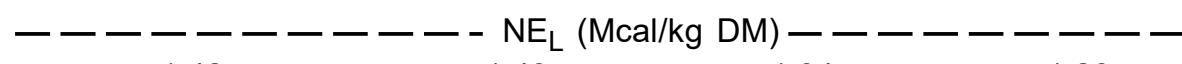 } \\
\hline Barley/100 & 1.42 & 1.43 & 1.34 & 1.26 \\
\hline Vetch/100 & 1.62 & 1.59 & 1.36 & 1.59 \\
\hline Barley:veza/65:35 & 1.41 & 1.40 & 1.37 & 1.29 \\
\hline Barley:Vetch/35:65 & 1.44 & 1.40 & 1.36 & 1.27 \\
\hline Oat/100 & 1.27 & 1.32 & 1.31 & 1.33 \\
\hline Oat:Vetch/65:35 & 1.24 & 1.23 & 1.36 & 1.31 \\
\hline Oat:Vetch/35:65 & 1.29 & 1.29 & 1.30 & 1.34 \\
\hline Triticale/100 & 1.25 & 1.26 & 1.29 & 1.17 \\
\hline Triticale:Vetch/65:35 & 1.20 & 1.26 & 1.22 & 1.21 \\
\hline Triticale:Vetch/35:65 & 1.28 & 1.33 & 1.25 & 1.19 \\
\hline
\end{tabular}

$\mathrm{ADF}=$ Acid detergent fiber; $\mathrm{TDN}=$ Total digestible nutrients; and $\mathrm{NE}_{\mathrm{L}}=$ Net energy for lactation. abcdef Different letters represent significant differences among treatments $(P<0.05)$. 
mayor cantidad de NDT la obtuvo el monocultivo veza con $66.7 \%$ durante la etapa lechoso. Le siguieron, el monocultivo cebada $(65.0 \%)$ y su mezcla con la veza (35:65; $64 \%)$, ambos valores obtenidos durante la etapa lechoso. El menor porcentaje de NDT la obtuvo la proporción triticale-veza (65:35), con $53.7 \%$ durante la etapa de embuche. Le siguió el monocultivo avena (54.4\%) y su mezcla con veza (65:35; $54.6 \%)$, ambos durante la etapa de embuche. No hubo interacción entre la mezcla de cultivos y la etapa de cosecha sobre el contenido de NDT $(P>0.05)$.

Los valores de ENL no fueron diferentes entre mezclas de cultivos ( $P>0.05$; Cuadro 1 ). Sin embargo, hubo un efecto de los monocultivos (cebada, avena, triticale) y su mezcla con la veza en dos proporciones de semilla (65:35; 35:65) sobre el contenido de ENL $(P<0.001$; Cuadro 3). La mayor cantidad de ENL la presentó el monocultivo veza con 1.62 Mcal $\mathrm{kg}^{-1} \mathrm{MS}$. No hubo efecto de la etapa de cosecha sobre la energía neta de lactancia ( $P>0.05$ ). Tampoco se encontró interacción entre la proporción de semilla y la etapa de cosecha sobre la ENL ( $P>0.05)$. and harvest stage on the RFV ( $P>0.05$ ). However, there was an effect from monocultures (barley, oat and triticale) and mixtures of these cereals in two vetch seed ratios (65:35, 35:65; $\mathrm{P}<0.001)$. In addition, there was an effect of the harvest stage on the RFV $(P<0.001)$. Furthermore, the effect of the seed ratio on RFV differ depending on the stage of harvest $(P<0.05$; Table 4). Thus, the vetch monoculture had higher values during the mature grain stage (167.2) and milky (152.0). It was followed by the oat monoculture with a value of 133.3. The lowest values were found for the triticale monoculture (82.0) and barley (84.6), followed by the ratios of triticale-vetch $(65: 35 ; 90.2)$ and barley-vetch $(35: 65 ; 91.8)$.

\section{DISCUSSION}

The results show that forage production and nutritional quality of vetch mixture with cereals (barley, oats and triticale) and two seed ratios $(65: 35 ; 35: 65)$ are associated with the phenological stage of harvest. Moreover, it was found that the oat-vetch mixture proved to be the association most suitable for crop DM production compared to triticale-vetch or barleyvetch mixtures. In particular, the ratio of oat-

Cuadro 4. Diferencias en el valor relativo del forraje (RFV) de monocultivos (cebada, avena y triticale) y la mezcla de estos cereales con la veza en dos proporciones de semilla $(65: 35,35: 65)$

Table 4. Differences in the relative feed value (RFV) in monocultures (barley, oat and triticale) and the mixture of these cereals with two vetch seed ratios $(65: 35,35: 65)$

\begin{tabular}{lcccc}
\hline & \multicolumn{4}{c}{ Phenological stages } \\
\cline { 2 - 5 } & Booting stage of grain & Milky grain & Doughy grain & Mature grain \\
\hline Barley/100 & $116.4^{\mathrm{bcd}}$ & $113.6^{\mathrm{bcd}}$ & $84.6^{\mathrm{a}}$ & $94.7^{\mathrm{abc}}$ \\
Vetch/100 & $140.2^{\mathrm{ef}}$ & $152.0^{\mathrm{fg}}$ & $110.4^{\mathrm{bcd}}$ & $167.2^{\mathrm{g}}$ \\
Barley:veza/65:35 & $113.6^{\mathrm{bcd}}$ & $111.3^{\mathrm{bcd}}$ & $92.0^{\mathrm{ab}}$ & $95.6^{\mathrm{abc}}$ \\
Barley:Vetch/35:65 & $109.0^{\mathrm{abc}}$ & $108.8^{\mathrm{abc}}$ & $91.8^{\mathrm{ab}}$ & $96.9^{\mathrm{abc}}$ \\
Oat/100 & $94.7^{\mathrm{ab}}$ & $133.3^{\mathrm{de}}$ & $119.0^{\mathrm{bcd}}$ & $124.3^{\mathrm{de}}$ \\
Oat:Vetch/65:35 & $92.0^{\mathrm{abc}}$ & $121.3^{\mathrm{cde}}$ & $126.8^{\mathrm{de}}$ & $121.0^{\mathrm{cde}}$ \\
Oat:Vetch/35:65 & $101.5^{\mathrm{abc}}$ & $123.5^{\mathrm{cde}}$ & $121.5^{\mathrm{cde}}$ & $125.8^{\mathrm{de}}$ \\
Triticale/100 & $92.0^{\mathrm{ab}}$ & $82.0^{\mathrm{a}}$ & $116.5^{\mathrm{bcd}}$ & $94.5^{\mathrm{abc}}$ \\
Triticale:Vetch/65:35 & $90.2^{\mathrm{ab}}$ & $112.8^{\mathrm{bcd}}$ & $106.0^{\mathrm{abc}}$ & $105.5^{\mathrm{abc}}$ \\
Triticale:Vetch/35:65 & $99.7^{\mathrm{abc}}$ & $121.3^{\mathrm{cde}}$ & $112.5^{\mathrm{bcd}}$ & $106.0^{\mathrm{abc}}$ \\
\hline
\end{tabular}

abcde Different letters represent significant differences among treatments $(P<0.05)$. 
El VRF no fue diferente entre mezclas de cultivos ( $P>0.05$; Cuadro 1). Tampoco hubo interacción entre la mezcla de cereales y etapa de cosecha sobre el VRF ( $P>0.05)$. Sin embargo, hubo un efecto entre los monocultivos (cebada, avena y triticale) y la mezclas de estos cereales con la veza en dos proporciones de semilla (65:35, 35:65; $P<0.001)$. También, hubo un efecto de la etapa de cosecha sobre el VRF $(P<0.001)$. Además, el efecto de la proporción de semilla sobre el VRF difirió dependiendo de la etapa de cosecha ( $P<0.05$; Cuadro 4). Así, el monocultivo veza presentó mayores valores durante las etapas grano maduro (167.2) y lechoso (152.0). Le siguió el monocultivo avena con un valor de 133.3. Los menores valores los presentaron los monocultivos triticale (82.0) y cebada (84.6), le siguieron las proporciones triticale-veza $(65: 35$; 90.2) y cebada-veza (35:65; 91.8).

\section{DISCUSIÓN}

Los resultados demuestran que la producción de forraje y la calidad nutritiva de la mezcla de veza con cereales (cebada, avena y triticale) en dos proporciones de semilla $(65: 35 ; 35: 65)$, se asocian con la etapa fenológica de cosecha. En efecto, la mezcla avena-veza resultó ser la asociación de cultivos más adecuada para la producción de MS comparado a las mezclas triticale-veza o cebada-veza. Particularmente, la proporción avena-veza (65:35) la cual produjo $40 \%$ más de MS durante la etapa grano lechoso-masoso que la mezcla triticale-veza, y $80 \%$ más que la mezcla cebada-veza. Estos resultados concuerdan con los obtenidos por Lithourgidis et $a(9)$; ellos demostraron que la mezcla veza común con avena (55:45) logró mayor producción de MS que la mezcla vezatriticale. En ese estudio, la mezcla veza-avena produjo $18 \%$ más de materia seca que la mezcla veza-triticale; además, la mezcla vezaavena, produjo $8 \%$ más de forraje seco que el monocultivo veza. Lo anterior se debe a que la avena muestra mayor complementariedad con la veza debido a que aprovecha mejor el nitrógeno fijado por esta leguminosa en el suelo en comparación con otras gramíneas. Otro factor vetch (65:35) produced $40 \%$ more DM during the milky-dough grain stage than the triticalevetch mixture, and $80 \%$ more than the barleyvetch mixture. These results agree with those obtained by Lithourgidis et $a /(9)$; they demonstrated that the mixture of common vetch with oat (55:45) achieved higher production of DM than triticale-vetch mixture. In that study, oat-vetch mixture produced $18 \%$ more dry matter than the mixture triticale-vetch. In addition, the vetch-oat mixture produced $8 \%$ more dry forage than vetch monoculture. This is because oats shows greater complementarity with vetch because better use nitrogen fixed by the legume on the ground compared to other grasses. Another factor may be the physical ability of species to grow; it has been shown that weight and plant height are higher in oatvetch mixtures than with barley-vetch or wheatvetch(18), furthermore oats grow better in competition; previous studies indicate that this crop shows a linear increase in competition with vetch as the density increases oat(11). These qualities allow the oats have better growth and consequently increased production of dry matter(19). For this reason, oat-vetch association is the best option for improving the dry matter production of vetch as reported in other studies(11). However, the harvesting stage is another factor that strongly influences the production of crop DM. Studies carried out regarding the optimal time for cutting show that for highest yield and quality for growing oats is in the milky and doughy grain stages, harvesting up to $19 \mathrm{t} \mathrm{ha}^{-1}$ of dry matter, similar to the data obtained in the present study(20).

The crude protein content in dry matter is important in assessing the nutritional quality of fodder(21). In the present study, the CP varied depending on the type of mixture and at what harvesting stage it was evaluated. The highest amount of crude protein was found in the mixtures oat-vetch and triticale-vetch during booting stage; and in terms of seed mixture ratios, the vetch monoculture obtained the highest during the grain mature stage, followed 
puede ser la capacidad física de las especies en crecer; se ha demostrado que el peso y la altura de la planta son más altos en mezclas de avena-veza que en asociaciones de cebada-veza o trigo-veza(18), además, la avena se adapta mejor a la competencia; estudios previos indican que este cultivo muestra un incremento lineal en competición con la veza conforme la densidad de la avena incrementa(11). Estas cualidades le permiten a la avena tener un mejor crecimiento y en consecuencia mayor producción de materia seca(19). Por esta razón, la asociación avenaveza es la mejor opción para mejorar la producción de materia seca de la veza tal como reportaron en otros estudios(11). Sin embargo, la etapa de cosecha es otro factor que influye fuertemente en la producción de MS de los cultivos. Estudios desarrollados al respecto indican que el momento óptimo de corte para rendimiento y calidad para el cultivo de la avena es en el estado grano lechoso y masoso con 19 t ha-1, dato similar al obtenido en el presente estudio(20).

El contenido de proteína cruda en la materia seca es importante para evaluar la calidad nutritiva del forraje(21). En el presente estudio, la PC varió en función del tipo de mezcla y de la etapa de cosecha en que se llevó a cabo la evaluación. La mayor cantidad de proteína cruda lo obtuvieron las mezclas avena-veza y triticaleveza durante la etapa de embuche; y en proporciones de semilla, la mayor cantidad la obtuvo el monocultivo veza durante la etapa grano maduro, le siguió la proporción avenaveza (35:65) durante la etapa de embuche. Una de las causas de la concentración de PC durante la etapa de embuche se debe a la captura de nitrógeno. Estudios al respecto indican que durante esta etapa, las plantas capturan mayor cantidad de nitrógeno inorgánico debido a la presencia de mayor cantidad de follaje(22). De hecho, algunos autores reportaron que durante ese tiempo la proporción grano: follaje es mayor (17:83), lo que permite tener mayor cantidad de proteína cruda en la planta (grano, $25.7 \%$; follaje $18.79 \%$ )(23). Datos reportados a la fecha indican que la inclusión de veza en los cereales mejora sustancialmente by oat-vetch $(35: 65)$ ratio during the booting stage. One cause of the high concentration of $\mathrm{CP}$ in the booting stage is due to the capture of nitrogen. Studies indicate that during this stage, plants capture the highest amount of inorganic nitrogen due to the presence of many leaves(22). In fact, some authors reported that during this time period the ratio of grain:foliage is greater (17:83), which allows greater amount of crude protein to be present in the plant (grain, $25.7 \%$; foliage $18.79 \%$ )(23). Data reported to nowadays indicate that the inclusion of vetch in cereals substantially improves CP content in the mixture, especially mixtures of oats and vetch(4). The inclusion of vetch with the cereal, improved significantly the CP content of the mixture. However, the increase depended more on the stage of harvest and not the ratio of cereal seed as reported in other studies $(9,24)$.

The neutral detergent fiber represents the structural or cell wall in the forage. This variable is inversely related to the amount that an animal is able to consume. Thus, forages with low NDF values have high intake levels than those with higher values. Therefore, a low value of NDF is desirable for ruminants(4). In this study, the low values of NDF where presented in the vetch monoculture (363 g kg-1 DM) and its mixture with oat $(35: 65 ; 407 \mathrm{~g})$ during the mature grain stage. Studies conducted in mixtures of oat with vetch indicate that the ratio of common vetch in oat is usually associated with an increase in the cellular content and a decrease in the $\operatorname{NDF}(11,25,26)$. However, in this study, low values NDF found in vetch and its mixture with oat depend more on the stage of harvest than the ratio of vetch seed in the mixture. This probably can be attributed to the decline of NDF values with increasing maturity of the forage due to a dilution effect created by an increase in the ratios of grain relative to the forage(4).

Acid detergent fiber mainly contains cellulose, lignin and silica(4). ADF low values represent high energy content and digestibility, which are 
el contenido de PC de la mezcla, sobre todo en mezclas de avena con veza(4). La inclusión de la veza en el cereal, mejoró de manera importante el contenido de PC de la mezcla. Sin embargo, el incremento dependió más de la etapa de cosecha y no de la proporción de semilla en el cereal, tal como lo reportan en otros estudios $(9,24)$.

La fibra detergente neutro, representa la pared estructural o celular en el forraje. Esta variable está inversamente relacionada a la cantidad que un animal es capaz de consumir. Así, forrajes con bajos valores de FDN tendrán altos niveles de consumo que aquéllos con valores altos. Por lo tanto, un valor bajo de FDN es deseable para los rumiantes(4). En este estudio, los bajos valores de FDN lo presentaron el monocultivo veza (363 g kg-1 MS) y su mezcla con avena (35:65; $407 \mathrm{~g}$ ) durante la etapa grano maduro. Estudios desarrollados en asociaciones de avena con veza indican que la proporción de veza común en la avena, es usualmente asociada con un incremento en el contenido celular y una disminución en la $\operatorname{FDN}(11,25,26)$. Sin embargo, en el presente estudio, los bajos valores de FDN encontrados en la veza y su mezcla con la avena dependió más de la etapa de cosecha que de la proporción de semilla de veza en la mezcla. Esto se debe probablemente a que el decline de los valores de FDN con el incremento en la madurez del forraje puede ser atribuido al efecto dilución creado por un incremento en la proporción de grano relativo al forraje(4).

La fibra detergente ácido contiene principalmente celulosa, lignina y sílice(4). Valores bajos de FDA representan contenidos altos de energía y digestibilidad, los cuales son deseables para los rumiantes. En el presente estudio, el contenido de FDA de la proporción de semilla en las mezclas dependió de la etapa de cosecha, siendo los monocultivos avena, veza y la proporción 35:65 triticale-veza los que presentaron menor cantidad de FDA durante la etapa grano lechoso. Algunos reportes indican que la inclusión de la veza en los cereales mejora la calidad nutritiva de la mezcla reduciendo el porcentaje de FDA en comparación al monocultivo(27). De acuerdo desirable for ruminants. In the present study, the ADF content of the seed ratios in mixtures depended on the stage of harvest, being monocultures oat, vetch and the ratio 35:65 triticale-vetch which showed fewer ADF during milky grain stage. Some reports indicate that the inclusion of vetch in cereals improves the nutritional quality of the mixture reducing the percentage of ADF compared to monoculture(27). According to what was observed in this study, only to the extent triticale-vetch $(35: 65)$ could have reduced levels of ADF by the presence of vetch; however, other mixtures including vetch in cereals (oat and barley) did not change significantly the content of ADF mixtures(9).

TDN content refers to the nutrients from the forage that are available to the animals, and these values are associated with ADF concentrations in the forage. In previous studies carried out on cereal mixtures (oat and triticale) with vetch indicate that the content of TDN decreases as the ratio of seed vetch increased in the mixture(9). In the present study, the ratio of vetch seed in cereals did not reduce the concentrations of TDN, since the vetch monoculture and mixed with barley (65:35) were those who had higher amounts of TDN. It is likely that the high values of TDN reported in common vetch are attributed on one hand to the low values of ADF present in vetch, but mainly to the phenological stage in which it was harvested.

$\mathrm{NE}_{\mathrm{L}}$ was not affected by the mixture of crops, nor by the harvest phenological stage. Only the vetch monoculture (1.62 Mcal $\mathrm{kg}^{-1} \mathrm{DM}$ ) presented higher values of $\mathrm{NE}_{\mathrm{L}}$ than the cereals. These results differ from those by Lithourgidis et $a(9)$, who reported that the net energy of lactation was similar for oat-vetch and triticalevetch mixtures and monocultures oat, triticale and vetch. Also, these same authors(28) found no significant differences between mixtures of vetch with barley or wheat vetch in terms of $\mathrm{NE}_{\mathrm{L}}$ content. It is likely that the content of $\mathrm{NE}_{\mathrm{L}}$ found in this study was due to sampling at the 
a lo observado en este estudio, únicamente en la proporción triticale-veza (35:65) se podrían haber reducido los niveles de FDA por la presencia de la veza; sin embargo, en las otras mezclas la inclusión de la veza en los cereales (avena y cebada) no cambió de manera importante el contenido de FDA de las mezclas $(9)$.

El contenido de NDT se refiere a los nutrientes del forraje que están disponibles para los animales, y estos valores están asociados a las concentraciones de FDA del forraje. En estudios previos desarrollados en mezclas de cereales (avena y triticale) con veza indicaron que el contenido de NDT disminuyó conforme se incrementó la proporción de semilla de veza en la mezcla(9). En el presente estudio, la proporción de semilla de veza en los cereales no redujo las concentraciones de NDT, ya que el monocultivo veza y su mezcla con cebada (65:35) fueron los que obtuvieron mayores cantidades de NDT. Es probable que los altos valores de NDT reportados en veza común sean atribuidos por un lado a los bajos valores de FDA presentes en la veza, pero principalmente a la etapa fenológica en que se cosechó.

La ENL no fue afectada por la mezcla de cultivos, ni por la etapa fenológica de cosecha. Únicamente el monocultivo veza (1.62 Mcal kg-1 MS) fue el que presentó mayor cantidad de ENL que los cereales. Estos resultados difieren de los reportados por Lithourgidis et $a(9)$, quienes mencionaron que la energía neta de lactancia fue similar para las mezclas avenaveza y triticale-veza y para los monocultivos avena, triticale y veza. También, estos mismos autores(28) no encontraron diferencias significativas entre mezclas de veza con cebada o veza con trigo sobre el contenido de ENL. Es probable que el contenido de ENL encontrado en el presente estudio se debió a la etapa fenológica de cosecha en que se llevó a cabo el muestreo, ya que en los estudios reportados por Lithorurgidis, la ENL se evaluó en el estado grano lechoso-masoso, mientras que en el presente estudio, no hubo una interacción entre el monocultivo y la etapa de cosecha. different phenological harvesting stages of the crop, since in the study reported by Lithorurgidis, $\mathrm{NE}_{\mathrm{L}}$ was evaluated in the milky-dough grain state, whereas in the present study, there was no interaction between monocultures and the harvest stage.

RFV is the index that is used to predict consumption and energy value of forage, and this is derived from the digestibility of dry matter and dry matter intake(29). Those forages with values greater than 151 are considered excellent(30). In the present study, vetch was the monoculture that presented the highest values (167.2) during the whole grain stage, which is considered excellent in animal feed. It was followed by the monoculture of oat with a value of 133 , which was not different from the vetch. Both values depended on the phenological stage of harvest.

\section{CONCLUSIONS AND IMPLICATIONS}

It can be concluded that the production and quality of vetch mixed forage with cereals (barley, oat and triticale) depend on the stage of harvest. In this study, oat-vetch mixture achieved higher production of dry matter and better crude protein content. In addition, the relative feed value was higher during the mature grain stage. These results suggest that oatvetch mixture may be a viable alternative for the production of good quality forage for ruminant feed during the winter.

\section{ACKNOWLEDGEMENTS}

We thank the COFUPRO-Fundación Produce Zacatecas for providing financial support through the project entitled "Technology transfer in cutting forage production and its conservation (silage in milk production)."

End of english version 
El VRF es el índice que es usado para predecir el consumo y valor energético de los forrajes, y éste se deriva de la digestibilidad de la materia seca y del consumo de materia seca(29). Aquellos forrajes con valores mayores a 151 son considerados como excelentes(30). En el presente estudio, la veza fue el monocultivo que presentó valores mayores (167.2) durante la etapa grano entero, lo cual es considerado como excelente en la alimentación animal. Le siguió el monocultivo avena con un valor de 133, el cual no fue diferente al de la veza. Ambos valores dependieron de la etapa fenológica de cosecha.

\section{CONCLUSIONES E IMPLICACIONES}

Se concluye que la producción y la calidad del forraje en mezcla de veza con cereales (cebada, avena y triticale) depende de la etapa de cosecha. En este estudio, la mezcla avena-veza logró mayor producción de materia seca y mejor contenido de proteína cruda. Además, el valor relativo del forraje fue más alto durante la etapa grano maduro. Estos resultados permiten sugerir que la mezcla avena-veza puede ser una alternativa viable para la producción de forraje de buena calidad en la alimentación de rumiantes durante el invierno.

\section{AGRADECIMIENTOS}

Se agradece a la COFUPRO-Fundación Produce Zacatecas por el apoyo financiero otorgado a través del proyecto titulado "Transferencia de tecnología en la producción de forrajes de corte y su conservación (ensilajes en la producción de leche)".

\section{LITERATURA CITADA}

1. Ofori F, Stern WR. Cereal-legume intercropping system. Adv Agron 1987;(41):41-90.

2. Francis, CA. Biological efficiencies in multiple cropping systems. Adv Agron 1989;(42):1-42.
3. Ghanbari-Bonjar A. Intercropped wheat (Triticum aestivum) and bean (Vicia faba) as a low-input forage [Ph.D thesis], Wye College, University of London, England. 2000.

4. Eskandari $H$, Ghanbari A, Javanmard A. Intercropping of cereals and legumes for forage production. Not Sci Biol 2009;(1):7-13.

5. Anil L, Park J, Phipps RH, Miller F. Temperate intercropping of cereal for forage: a review of potential for growth and utilization with particular reference to the UK. Grass Forage Sci 1998;(53):301-317.

6. Thomson EF, Rihawi $\mathrm{S}$, Nersoyan N. Nutritive value and yields of some forage legumes and barley harvested as immature herbage, hay and straw in North-West Syria. Exp Agric 1990;(26):49-56.

7. Caballero R, Goicoechea EL. Utilization of winter cereals as companion crops for common vetch and hairy vetch. Barba FM, Abreu JM editors. Grasslands facing the energy crisis. Proc General Meet European Grassland Federation. 1986:379-384.

8. Thompson DJ, Stout DG, Moore T. Forage production by 4 annual cropping sequences emphasizing barley under irrigation in southern interior British Columbia. Can J Plant Sci 1992;(72):181-185.

9. Lithourgidis AS, Vasilakoglou IB, Dhima KV, Dordas $\mathrm{CA}_{\text {, }}$ Yiakoulaki MD. Forage yield and quality of common vetch mixtures with oat and triticale in two seeding ratio. Field Crops Res 2006;(99):106-113.

10. Qamar IA, Keatinge JDH, Mohammad N, Ali A, Khan MA. Introduction and management of common vetch/barley forage mixtures in the rainfed areas of Pakistan. 3. Residual effects on following cereal crops. Aust J Agric Res 1999;(50):21-27.

11. Caballero R, Goicoechea EL, Hernaiz PJ. Forage yields and quality of common vetch and oat sown varying seeding ratios and seeding rates of vetch. Field Crops Res 1995;(41):135-140.

12. Núñez HG, Payán GJ, Peña RA, González CF, Ruiz BO, Arzola AC. Caracterización agronómica y nutricional del forraje de variedades de especies anuales en la región norte de México. Téc Pecu Méx 2010;1(2):85-98.

13. Echavarría CHFG, Serna PA, Flores NMJ, Medina GG, Gutiérrez LR, Salinas GH, et al. Sistema de producción de forrajes de temporal una opción para la reconversión productiva. Campo Experimental Zacatecas. CIRNOC.INIFAP. Folleto Técnico No. 53. 2014.

14. AOAC. Official Methods of Analysis. 16th ed. Assoc. Off Anal Chem, Arlington, VA. 1996.

15. Georing HK, Van Soest PJ. Forage fiber analysis: Apparatus reagents, procedures, and some applications. Agric 1970. Handbook 379.

16. Horrocks RD, Vallentine JF. Harvested forage. London, UK: Academic Press; 1999.

17. SYSTAT 13, 2013. Chicago, IL, USA.

18. Ansar M, Ahmed ZI, Malik MA, Nadeem M, Majeed A, Rischkowsky BA. Forage yield and quality potential of winter cereal-vetch mixtures under rainfed conditions. Emir J Food Agric 2010;22(1):25-36.

19. Jannink JL, Liebman M, Merrick LC. Biomass production and nitrogen accumulation in pea, oat and vetch Green manure mixtures. Agron J 1996;88:231-240. 
20. Espitia RE, Villaseñor ME, Tovar GR, de la O OM, Limón OA. Momento óptimo de corte para rendimiento y calidad de variedades de avena forrajera. Rev Méx Cienc Agr 2012;3(4):771-783.

21. Assefa G, Ledin I. Effect of variety, soil type and fertilizer on the establishment, growth, forage yield, quality and voluntary intake by cattle of oats and vetches cultivated in pure stands and mixtures. Anim Feed Sci Technol $2001 ;(92): 95-111$.

22. Verhulst N, François I, Grahmann K, Cox R, Govaerts B. Nitrogen use efficiency and optimization of nitrogen fertilization in conservation agriculture. CAB Reviews 2013;8:053.

23. Ramírez-Ordóñes $S$, Domínguez-Díaz $D$, Salmerón-Zamora JJ, Villalobos-Villalobos G, Ortega-Gutiérrez JA. Producción y calidad del forraje de variedades de avena en función del sistema de siembra y de la etapa de madurez al corte. Rev Fitotec Mex 2013;36(4):395-403.

24. Bingol NT, Karsu MA, Yilmaz IH, Bolat D. The effects of planting time and combination on the nutrient composition and digestible dry matter yield of four mixtures of vetch varieties intercropped with barley. Turk J Vet Anim Sci 2007;(31):297-302.
25. Haj-Ayed M, González J, Caballero R, Alvir MR. Nutritive value of on-farm common vetch-oat hays. II. Ruminal degradation of dry matter and crude protein. Ann Zootech 2000;(49):391-398.

26. Erol E, Kaplan M, Kizilsimsek M. Oats (Avena sativa) common vetch (Vicia sativa) mixtures grown on a lowinputs basis for a sustainable agriculture. Trop Grasslands 2009;(43):191-196.

27. Yolcu H, Dasci M, Tan M. Evaluation of annual legumes and barley as sole crops and intercrop in spring frost conditions for animal feeding. I. Yield and quality. J Anim Vet Adv 2009;(7):1337-1342.

28. Lithourgidis AS, Dhima KV, Vasilakoglou IB, Dordas CA, Yiakoulaki MD. Sustainable production of barley and wheat by intercropping common vetch. Agron Sustain Dev 2007; (27):95-99.

29. Moore JE, Undersander DJ. Relative forage quality: An alternative to relative feed value and quality index. Proc 13th Ann Florida Rum Nut Symp. Florida. 2002:16-32.

30. Horrocks RD, Vallentine JF. Harvested forages, London, UK: Academic Press; 1999. 